\title{
Glucagon-like Peptide-1 Receptor as Emerging Target: Will It Make It to the Clinic?
}

\author{
Damian Wild ${ }^{1,2}$, Kwadwo Antwi ${ }^{1}$, Melpomeni Fani ${ }^{3}$, and Emanuel R. Christ ${ }^{2,4}$ \\ ${ }^{I}$ Division of Nuclear Medicine, University Hospital Basel, Basel, Switzerland; ${ }^{2}$ Center for Neuroendocrine and Endocrine Tumors, \\ University Hospital Basel, Basel, Switzerland; ${ }^{3}$ Division of Radiopharmaceutical Chemistry, University Hospital Basel, Basel, \\ Switzerland; and ${ }^{4}$ Division of Endocrinology, Diabetology and Metabolism, University Hospital Basel, Basel, Switzerland
}

\begin{abstract}
The glucagon-like peptide-1 receptor (GLP-1R) is an emerging target due to its high expression in benign insulinomas as well as in islet cell hypertrophia/hyperplasia (nesidioblastosis) and pancreatic $\beta$-cells. In 2008, occult insulinomas were localized for the first time in men using the metabolically stable radiolabeled glucagon-like peptide-1 (GLP-1) agonist [Lys ${ }^{40}$ (Ahx-DTPA- ${ }^{111}$ In) $\mathrm{NH}_{2}$ ]-exendin-4 $\left({ }^{111}\right.$ In-DTPA-exendin4). Afterward, several radiopharmaceuticals for GLP-1R PET/ CT imaging were synthesized and evaluated, for example, $\left[\mathrm{Nle}^{14}{ }^{14}\right.$,ys $\left.{ }^{40}\left(\mathrm{Ahx}-\mathrm{DOTA}-{ }^{68} \mathrm{Ga}\right) \mathrm{NH}_{2}\right]$-exendin-4 $\quad\left({ }^{68} \mathrm{Ga}-\mathrm{DOTA}-\right.$-exendin4), $\left[\right.$ Cys $^{40}$ (MAL-NOTA- $\left.{ }^{68} \mathrm{Ga}\right) \mathrm{NH}_{2}$ ]-exendin-4 ( $\left.{ }^{68} \mathrm{Ga}-\mathrm{NOTA}-e x e n d i n-4\right)$, and $\left[\mathrm{Lys}^{40}\right.$ (NODAGA- $\left.{ }^{68} \mathrm{Ga}\right) \mathrm{NH}_{2}$ ]-exendin-4 $\left({ }^{68} \mathrm{Ga}-\mathrm{NODAGA}-\right.$ exendin4). Several prospective comparison studies provided evidence that GLP-1R PET/CT is significantly more sensitive than contrastenhanced MRI (ceMRI), contrast-enhanced CT (ceCT), GLP-1R SPECT/CT, somatostatin receptor PET/CT, and SPECT/CT in the detection of benign insulinomas, and insulinomas in the context of multiple endocrine neoplasia type 1. As a result, the European Neuroendocrine Tumor Society guidelines recommend GLP-1R imaging or selective intraarterial calcium stimulation and venous sampling (ASVS) in patients for whom there is a clinical suspicion of having an insulinoma but who have a negative ceMRI/ceCT or negative endoscopic ultrasound. Furthermore, there is growing evidence that GLP-1R PET/ CT can visualize and localize adult nesidioblastosis. This is clinically relevant as the distinction between focal and diffuse nesidioblastosis is critical in directing a therapeutic strategy in these patients. Prospective studies have proven the clinical relevance of GLP-1R imaging as it is often the only imaging modality able to localize the insulinoma or nesidioblastosis. It is therefore likely that this noninvasive imaging modality will replace the invasive localization of insulinomas using ASVS. More experimental indications for GLP-1R imaging include the diagnosis of an insulinoma/nesidioblastosis in patients with postprandial hypoglycemia after bariatric bypass surgery and monitoring $\beta$-cells in patients with brittle type 1 diabetes after islet-cell transplantation. We believe that these indications and possibly future indications will bring GLP-1R imaging to the clinic.
\end{abstract}

Key Words: glucagon-like peptide-1 receptor (GLP-1R) imaging; exendin-3; exendin-4; insulinoma; nesidioblastosis; $\beta$-cell imaging

J Nucl Med 2021; 62:44S-50S

DOI: 10.2967/jnumed.120.246009

$\mathbf{T}$ he glucagon-like peptide-1 receptor (GLP-1R) was characterized and cloned approximately $25 \mathrm{y}$ ago (1). It is of clinical interest

Received Jul. 15, 2020; revision accepted Sep. 11, 2020.

For correspondence or reprints, contact Damian Wild (damian.wild@usb.ch). COPYRIGHT (C) 2021 by the Society of Nuclear Medicine and Molecular Imaging. not only due to its physiologic expression and function in pancreatic $\beta$-cells (2) and its established role in the therapy of type 2 diabetes using glucagon-like peptide-1 (GLP-1) analogs (3), but also because of its possible role as a target for the detection of tumors and other diseases with nuclear medicine imaging methods.

Current preclinical and clinical evaluation of radiolabeled GLP-1 analogs for SPECT/CT and PET/CT imaging, as well as their clinical potential, are discussed here.

\section{GLP-1R TARGETING: PRECLINICAL DEVELOPMENTS}

Exendin-4 (H-His ${ }^{1}-\mathrm{Gly}^{2}-\mathrm{Glu}^{3}-\mathrm{Gly}^{4}-\mathrm{Thr}^{5}-\mathrm{Phe}^{6}-\mathrm{Thr}^{7}-\mathrm{Ser}^{8}-\mathrm{Asp}^{9}-$ $\mathrm{Leu}^{10}-\mathrm{Ser}^{11}-\mathrm{Lys}^{12}-\mathrm{Gln}^{13}-\mathrm{Met}^{14}-\mathrm{Glu}^{15}-\mathrm{Glu}^{16}-\mathrm{Glu}^{17}-\mathrm{Ala}^{18}-\mathrm{Val}^{19}-\mathrm{Arg}^{20}{ }^{20}$ $\mathrm{Leu}^{21}-\mathrm{Phe}^{22}-\mathrm{Ile}^{23}-\mathrm{Glu}^{24}-\mathrm{Trp}^{25}{ }^{2} \mathrm{Leu}^{26}-\mathrm{Lys}^{27}-\mathrm{Asn}^{28}{ }^{2} \mathrm{Gly}^{29}-\mathrm{Gly}^{30}-\mathrm{Pro}^{31}$ $\mathrm{Ser}^{32}-\mathrm{Ser}^{33}-\mathrm{Gly}^{34}-\mathrm{Ala}^{35}-\mathrm{Pro}^{36}-\mathrm{Pro}^{37}-\mathrm{Pro}^{38}-\mathrm{Ser}^{39}-\mathrm{NH}_{2}$ ) is a naturally occurring GLP-1R peptide agonist sharing 53\% homology with the respective human hormone GLP-1, while being metabolically more resistant ( $2.4 \mathrm{~h}$ vs. $2 \mathrm{~min}$ ). Exendin-3 is also a highly stable 39 -amino acid peptide that differs from exendin- 4 only by 2 amino acid residues near the $\mathrm{N}$ terminus $\left(-\mathrm{Ser}^{2}-\mathrm{Asp}^{3}-\right)$. After the pioneer work with ${ }^{123}$ I-labeled exendin-3 in an insulinoma animal model (4), several radiotracers based on exendin-3 and exendin-4 (Byetta; AstraZeneca) have been developed $(5,6)$. Among them, exendin-4-based radiotracers were advancing into patients (Table 1).

\section{Radiotracers Based on Exendin-4}

Exendin- 4 was initially modified at the $\mathrm{C}$ terminus by the introduction of $\mathrm{Lys}^{40}$, at the side chain of which the linker Ahx (aminohexanoic acid), followed by the chelator DTPA (diethylenetriaminepentaacetic acid), were conjugated. [Lys ${ }^{40}$ (AhxDTPA- $\left.{ }^{111} \mathrm{In}\right) \mathrm{NH}_{2}$ ]-exendin-4 showed remarkably high tumor uptake and tumor-to-background contrast in transgenic Rip1Tag2 mice that develop GLP-1R-expressing tumors in the pancreatic islets (7).

${ }^{99 m}$ Tc-labeled exendin-4 using HYNIC (hydrazinonicotinamide) with EDDA (ethylenediaminetetraacetic acid) as coligand and ${ }^{68}$ Ga-labeled exendin-4 using DOTA (1,4,7,10-tetraazacyclododecan-1,4,7,10-tetraacetic acid) followed. $\left[\right.$ Lys $^{40}$ (Ahx-DOTA- ${ }^{68}$ $\mathrm{Ga}) \mathrm{NH}_{2}$ ]-exendin-4 had a biodistribution and tumor uptake similar to $\left[\mathrm{Lys}^{40}\left(\mathrm{Ahx}-\mathrm{DOTA}-{ }^{111} \mathrm{In}\right) \mathrm{NH}_{2}\right]$-exendin-4, whereas $\left[\mathrm{Lys}^{40}\left(\mathrm{Ahx}-\mathrm{HYNIC}-{ }^{99 \mathrm{~m}} \mathrm{Tc} / \mathrm{EDDA}\right) \mathrm{NH}_{2}\right.$ ]-exendin-4 had significantly lower tumor uptake, but as well lower uptake in the nontargeted organs (8). Consequently, image quality was high for all 3 radiotracers, which were then rapidly translated into clinical applications.

Newer developments addressed potential drawbacks, including radiochemical purity, specific activity (linked to the administered peptide mass), and the high and persistent kidney uptake. 
TABLE 1

List of the Most Advanced Radiotracers for GLP-1R Imaging

\begin{tabular}{|c|c|c|c|c|c|c|}
\hline Peptide & Chelator & Linker & Conjugate & Radionuclide & Short name & Status \\
\hline Lys $^{40}$-exendin-4 & DTPA & Ahx & $\begin{array}{l}{\left[\text { Lys }^{40}(\mathrm{Ahx}-\mathrm{DTPA}) \mathrm{NH}_{2}\right]-} \\
\quad \text { exendin-4 }\end{array}$ & ${ }^{111}$ In & ${ }^{111}$ In-DTPA-exendin-4 & $\begin{array}{l}\text { Prospective } \\
\text { phase I/II }\end{array}$ \\
\hline Lys $^{40}$-exendin-4 & HYNIC/EDDA & Ahx & $\begin{array}{l}{\left[\text { Lys }^{40}(\mathrm{Ahx}-\mathrm{HYNIC}) \mathrm{NH}_{2}\right]-} \\
\quad \text { exendin-4 }\end{array}$ & ${ }^{99 \mathrm{~m}} \mathrm{Tc}$ & ${ }^{99 m}$ Tc-HYNIC-exendin-4 & $\begin{array}{l}\text { Preliminary } \\
\text { clinical data }\end{array}$ \\
\hline Lys $^{40}$-exendin-4 & DOTA & Ahx & $\begin{array}{l}{\left[\text { Lys }^{40}(\mathrm{Ahx}-\mathrm{DOTA}) \mathrm{NH}_{2}\right]-} \\
\quad \text { exendin-4 }\end{array}$ & ${ }^{111} \mathrm{In},{ }^{68} \mathrm{Ga}$ & ${ }^{111}$ In-DOTA-exendin-4 & $\begin{array}{l}\text { Prospective } \\
\text { phase I/II }\end{array}$ \\
\hline $\mathrm{Nle}^{14}$, Lys $^{40}$-exendin-4 & DOTA & Ahx & $\begin{array}{l}\text { [Nle }^{14} \text {,Lys }^{40}(\mathrm{Ahx}- \\
\left.\text { DOTA }) \mathrm{NH}_{2}\right] \text {-exendin-4 }\end{array}$ & ${ }^{111} \mathrm{In},{ }^{68} \mathrm{Ga}$ & ${ }^{68} \mathrm{Ga}-\mathrm{DOTA}$-exendin-4 & $\begin{array}{l}\text { Prospective } \\
\text { phase I/II }\end{array}$ \\
\hline Lys $^{40}$-exendin-4 & NODAGA & - & $\begin{array}{l}{\left[\text { Lys }^{40}(\mathrm{NODAGA}) \mathrm{NH}_{2}\right]-} \\
\quad \text { exendin- } 4\end{array}$ & ${ }^{68} \mathrm{Ga}$ & $\begin{array}{l}{ }^{68} \text { Ga-NODAGA- } \\
\text { exendin-4 }\end{array}$ & $\begin{array}{l}\text { Preliminary } \\
\text { clinical data }\end{array}$ \\
\hline Cys ${ }^{40}$-exendin-4 & NOTA & (MAL) & $\begin{array}{l}{\left[\mathrm{Cys}^{40}(\mathrm{MAL}-\mathrm{NOTA}) \mathrm{NH}_{2}\right]-} \\
\quad \text { exendin-4 }\end{array}$ & ${ }^{68} \mathrm{Ga}\left({ }^{18} \mathrm{~F}\right)$ & ${ }^{68} \mathrm{Ga}-\mathrm{NOTA}$-exendin-4 & $\begin{array}{r}\text { Prospective } \\
\text { phase I/II }\end{array}$ \\
\hline Cys $^{40}$-exendin- 4 & DO3A & (VS) & $\begin{array}{l}{\left[\mathrm{Cys}^{40}(\mathrm{VS}-\mathrm{DO} 3 \mathrm{~A}) \mathrm{OH}\right]-} \\
\quad \text { exendin-4 }\end{array}$ & ${ }^{68} \mathrm{Ga}$ & $\begin{array}{l}{ }^{68} \mathrm{Ga}-\mathrm{DO} 3 \mathrm{~A}-\mathrm{VS}-\mathrm{Cys}^{40}{ }_{-} \\
\text {exendin-4 }\end{array}$ & Case report \\
\hline
\end{tabular}

\section{Further Optimization and Specific Activity}

Replacement of $\mathrm{Met}^{14}$, being susceptible to oxidation, by the nonoxidizing isosteric analog norleucine (Nle) resulted in $\left[\mathrm{Nle}^{14}\right.$, $\mathrm{Lys}^{40}$ (Ahx-DOTA)NH $\mathrm{N}_{2}$ ]-exendin-4 for ${ }^{68} \mathrm{Ga}$ and ${ }^{111}$ In labeling with higher radiochemical purity $(9,10)$.

Focusing on PET imaging, NODAGA (1,4,7-triazacyclononane, 1-glutaric acid-4,7 acetic acid) was used for improving radiochemical purity and specific activity, as it forms stable complexes with ${ }^{68} \mathrm{Ga}$ in milder conditions than DOTA. [Lys ${ }^{40}$ (NODAGA$\left.{ }^{68} \mathrm{Ga}\right) \mathrm{NH}_{2}$ ]-exendin-4 was developed within a EU FP7 project (BetaCure), but no evidence of improvement versus the DOTA conjugate exists.

A variant of exendin- 4 by introducing $\mathrm{Cys}^{40}$ and conjugating NOTA (1,4,7-triazacyclononane-1,4,7-triacetic acid) functionalized as mono N-ethylmaleimide (MAL) was initially developed for ${ }^{18} \mathrm{~F}$ labeling via ${ }^{18} \mathrm{~F}$-AlF (11). Nevertheless, the ${ }^{68} \mathrm{Ga}$ counterpart $\left[\mathrm{Cys}^{40}\left(\mathrm{MAL}-\mathrm{NOTA}-{ }^{68} \mathrm{Ga}\right) \mathrm{NH}_{2}\right.$ ]-exendin-4 was the one translated into clinical practice. The other variant, ${ }^{68} \mathrm{Ga}-\mathrm{DO} 3 \mathrm{~A}-\mathrm{VS}-$ $\mathrm{Cys}^{40}$-exendin-4 (VS = vinyl sulfone and DO3A $=1,4,7$-tris (carboxymethyl)-1,4,7,10-tetraazacyclododecane), showed improved specific activity versus the DOTA conjugate and the potential of GLP-1R quantification in the pancreas of rodents and nonhuman primates (12).

\section{Antagonists and Reduction of Pancreatic Background Activity}

The use of antagonists is attractive for avoiding activation of the GLP-1R signaling that induces glucose-dependent insulin secretion. Unfortunately, all radiolabeled variants of the antagonist exendin(9-39) were proven to be unsuitable, due to their low tumor uptake $(13,14)$. Surprisingly, $\left[{ }^{125} \mathrm{I}-\mathrm{BH}-\mathrm{Lys}{ }^{27}\right]$-exendin $(9-$ 39) $\mathrm{NH}_{2}\left({ }^{125} \mathrm{I}\right.$-Bolton-Hunter in the residue Lys $\left.{ }^{27}\right)$, was the only antagonist with a tumor uptake similar to the agonists, and in addition, significantly lower kidney uptake (14).

Low kidney uptake and subsequent low pancreatic background activity is an important prerequisite for the therapeutic use of radiolabeled GLP-1 analogs as well as the quantification of pancreatic $\beta$-cells. In fact, the high kidney uptake are characteristics of radiometal-labeled exendin- 4 tracers, which are potentially addressed by ${ }^{18} \mathrm{~F}$ - or ${ }^{125 / 124} \mathrm{I}$-labeled tracers (5). However, fluorinated or iodinated radiotracers are not easy in routine clinical production. Alternatively, other approaches were tested for kidney uptake reduction. Among them, the use of polyglutamic acid, gelofusine or albumin fragments and the introduction of cleavable linkers show significant reduction of the kidney uptake $(5,6)$. Another option to circumvent the high kidney uptake, and consequently reduce the pancreatic background activity, is the use of positron emitters that allow late-time-point imaging, such as ${ }^{64} \mathrm{Cu}$ or ${ }^{89} \mathrm{Zr}$.

\section{Physiologic and Pathologic GLP-1R Expression in Humans}

Only a single GLP-1R is known so far, which is structurally identical in all tissues (1). Tissue samples from 32 different tumors as well as normal tissue were screened for GLP-1R expression using in vitro receptor autoradiography with a GLP-1R-specific radiotracer, ${ }^{125} \mathrm{I}-\mathrm{GLP}-1(7-36) \mathrm{NH}_{2} \quad(15-18)$. The most striking GLP-1R expression with an almost $100 \%$ incidence and extremely high density was found in benign insulinomas (15), later also in vivo in insulinomas as part of the multiple endocrine neoplasia type 1 (MEN-1) syndrome, an autosomal dominant inherited tumor syndrome (19). No other peptide receptor, including somatostatin receptor (SSTR) subtype 2, exhibited such high expression levels in benign insulinomas (15). Table 2 summarizes the relevant GLP-1R expression in different tumors and normal tissue notably in the neurohypophysis, Brunner's glands of the duodenum, pancreatic $\beta$-cells (2), and acini (Fig. 1). Importantly, the GLP-1R density in pancreatic $\beta$-cells is about 6 times lower than in insulinomas, resulting in good insulinoma-to-background contrast favorable for imaging (Fig. 1). Furthermore, there is an increased GLP-1R expression in pancreatic islet cell hypertrophy/ hyperplasia also known as nesidioblastosis, which was first described in children and neonates and is characterized by endogenous hyperinsulinemic hypoglycemia (EHH; congenital hyperinsulinism). So far, the GLP-1R incidence and density in islet cell hypertrophy/hyperplasia was primarily quantified in adult nesidioblastosis after gastric bypass surgery (17), which is another 
TABLE 2

GLP-1R Expression in Different Diseases and Normal Organs

\begin{tabular}{|c|c|c|c|c|}
\hline $\begin{array}{c}\text { Characteristics of GLP-1R } \\
\text { expression }\end{array}$ & Tissue sample & $\begin{array}{l}\text { GLP-1R } \\
\text { density }^{*}\end{array}$ & $\begin{array}{l}\text { GLP-1R } \\
\text { incidence }\end{array}$ & Reference \\
\hline $\begin{array}{l}\text { Disease with high GLP-1R } \\
\text { density and incidence }\end{array}$ & Benign insulinoma & 8133 & $25 / 27,93 \%$ & $(15,19)$ \\
\hline $\begin{array}{l}\text { Diseases with high GLP-1R } \\
\text { density but moderate } \\
\text { incidence }\end{array}$ & Malignant insulinoma & 8508 & $4 / 11,36 \%$ & $(18)$ \\
\hline \multirow{2}{*}{$\begin{array}{l}\text { Diseases with moderate GLP-1R } \\
\text { density but high incidence }\end{array}$} & Gastrinoma & 2461 & $10 / 10,100 \%$ & $(15)$ \\
\hline & $\begin{array}{l}\text { Adult nesidioblastosis after } \\
\text { gastric bypass surgery }\end{array}$ & 1483 & $7 / 7,100 \%$ & $(17)$ \\
\hline \multirow{4}{*}{$\begin{array}{l}\text { Diseases with moderate GLP-1R } \\
\text { density and incidence }\end{array}$} & Pheochromocytoma & 3970 & $12 / 20,60 \%$ & $(16)$ \\
\hline & NETs of the lung & 2456 & $11 / 29,38 \%$ & (15) \\
\hline & Paraganglioma & 1353 & $5 / 18,28 \%$ & (16) \\
\hline & $\begin{array}{l}\text { Medullary thyroid } \\
\text { carcinoma }\end{array}$ & 1326 & $5 / 18,28 \%$ & (16) \\
\hline $\begin{array}{l}\text { Disease with expected GLP-1R } \\
\text { expression }\end{array}$ & Congenital hyperinsulinism & ND & ND & \\
\hline \multirow[t]{5}{*}{ Organs with GLP-1R expression } & Neurohypophysis & 5207 & $6 / 6,100 \%$ & $(16)$ \\
\hline & $\begin{array}{l}\text { Duodenum Brunner's } \\
\text { glands }\end{array}$ & 2752 & $5 / 5,100 \%$ & (16) \\
\hline & Pancreas islets & 1322 & $24 / 24,100 \%$ & $(16)$ \\
\hline & Pancreas acini & 693 & $9 / 9,100 \%$ & \\
\hline & $\begin{array}{l}\text { Kidney, large- and } \\
\text { medium-sized arteries }\end{array}$ & 674 & $2 / 2,100 \%$ & (16) \\
\hline
\end{tabular}

${ }^{*} \mathrm{GLP}-1 \mathrm{R}$ density is given as mean in degradation per minutes per mg tissue (dpm/mg tissue). ND = not done.

clinical syndrome with mainly postprandial hypoglycemia, typically occurring after bariatric surgery (20).

\section{GLP-1R IMAGING: CLINICAL EVALUATION AND COMPARISON WITH OTHER IMAGING MODALITIES}

Preoperative localization of benign insulinomas is currently the most relevant indication of GLP-1R imaging. Insulinomas secrete insulin in an autonomous way, resulting in life-threatening hypoglycemia (EHH). Since complete tumor resection cures patients with benign insulinomas, the exact preoperative localization of insulinoma is critical to facilitate pancreas-preserving surgery such as limited segmental resection or enucleation (21). Benign insulinomas are difficult to localize with conventional radiologic procedures (contrast-enhanced MRI [ceMRI] and contrast-enhanced CT [ceCT]; sensitivity between $47 \%$ and 90\% (22-27)) (Table 3). This is because of the small size of insulinomas $(1-2 \mathrm{~cm})$, lack of contrast, and motion artifacts (respiratory motion, cardiac pulsation, and bowel peristalsis).

\section{Detection of Insulinomas with GLP-1R Imaging}

In 2008, occult insulinomas were localized for the first time in humans using the metabolically stable ${ }^{111}$ In-labeled GLP-1 agonist ${ }^{111}$ In-DTPA-exendin-4 (28). ${ }^{11}$ In-DTPA-exendin-4, ${ }^{111}$ In-DOTAexendin-4, and ${ }^{99 \mathrm{~m}}$ Tc-HYNIC-exendin-4 scintigraphy and SPECT/CT were highly sensitive in the detection of benign insulinomas (29-31) but inferior to GLP-1R PET/CT with ${ }^{68}$ Ga-DOTA- exendin-4, ${ }^{68}$ Ga-NOTA-exendin-4, or ${ }^{68}$ Ga-NODAGA-exendin-4, which showed sensitivities between $85 \%$ and $98 \%(22,24,32)$ (Tables 1 and 3). Importantly, ${ }^{111} \mathrm{In}$ - and ${ }^{99 \mathrm{~m}}$ Tc-labeled exendin-4 can also be used for intraoperative localization of hidden insulinomas using a $\gamma$-probe (30). Prospective comparison of ${ }^{68} \mathrm{Ga}-$ DOTA-exendin- $4 /{ }^{68}$ Ga-NOTA-exendin-4 PET/CT with ceMRI or ceCT in the same patients showed significant higher sensitivities for PET/CT in the detection of benign insulinomas (95\%/98\% vs. $69 \%$ or $74 \%)(22,24)$. Consequently, European Neuroendocrine Tumor Society guidelines recommend GLP-1R imaging or intraarterial calcium stimulation and venous sampling (ASVS) in patients with $\mathrm{EHH}$ with negative ceMRI/ceCT or negative endoscopic ultrasound (EUS) results (21). Methods such as ASVS and EUS show also high sensitivities (between 65\% and 100\%, Table 3) but are invasive and in the case of ASVS do not indicate the localization but the arterial supply of the insulinoma. A prospective comparison of GLP-1R PET/CT with different imaging modalities including EUS showed sensitivities of $98 \%$ for GLP-1R PET/CT and $85 \%$ for EUS, which was not significantly different (24).

Recently it was shown that ${ }^{68} \mathrm{Ga}$-DOTA-exendin-4 PET/CT can specifically identify insulin-producing tumors (insulinomas) in the context of MEN-1 (19). This is clinically relevant because $80 \%$ of patients with MEN-1 develop repetitive, multiple pancreatic neuroendocrine tumors (NET), either functioning or nonfunctioning, which can become life-threatening due to hypoglycemia or malignant progression (19). Therefore, European Neuroendocrine 


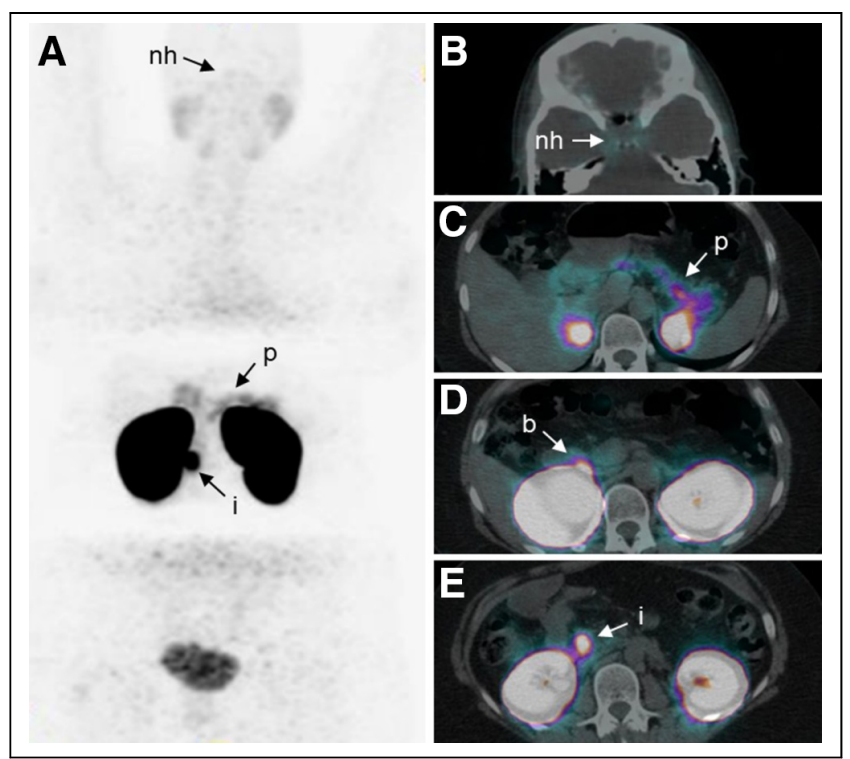

FIGURE 1. ${ }^{68} \mathrm{Ga}$-DOTA-exendin-4 PET and PET/CT of a patient with a histologically confirmed benign insulinoma. Whole-body maximum-intensity-projection PET (A) shows intense focal ${ }^{68} \mathrm{Ga}-\mathrm{DOTA}$-exendin-4 accumulation in a benign insulinoma (i) located in head of pancreas with good contrast compared with normal pancreas (p). Transaxial PET/CT indicates low ${ }^{68} \mathrm{Ga}-\mathrm{DOTA}$-exendin-4 uptake (B) in neurohypophysis (nh), moderate ${ }^{68} \mathrm{Ga}$-DOTA-exendin-4 uptake (C) in normal pancreas (p), and high ${ }^{68} \mathrm{Ga}-$ DOTA-exendin-4 uptake (D) in Brunner's glands of duodenum (b) and $(E)$ in insulinoma (i).

Tumor Society recommends in patients with MEN-1 background a pancreas-preserving resection of clinically relevant NET that includes insulinomas independent of size and nonfunctioning NET with a diameter of $\geq 20 \mathrm{~mm}$ (21). In such patients, the detection of clinically relevant lesions is significantly higher with a combination of ${ }^{68} \mathrm{Ga}$-DOTA-exendin-4 PET/CT plus MRI than just with MRI ( $92 \%$ vs. 39\%), as MRI determines only size but not functionality of the lesion (19).

GLP-1R imaging is much less sensitive in the detection of malignant insulinomas than benign insulinomas because malignant insulinomas express the GLP-1R with an incidence of $<40 \%$ (Table 2) (18). Furthermore, radiolabeled GLP-1 agonists show high accumulation in the kidneys (Fig. 1), restricting the therapeutic use of such compounds. Conversely, malignant insulinomas often express SSTR2 (incidence of 73\%), which can be successfully targeted therapeutically (18) using SSTR peptide receptor radionuclide therapy (33).

\section{Detection of Insulinomas with Alternative Nuclear Medicine Methods}

Alternative nuclear medicine methods for localizing insulinomas include SSTR PET/CT, SSTR SPECT/CT, and ${ }^{18} \mathrm{~F}$-fluorodopa $\left({ }^{18}\right.$ F-DOPA) PET/CT (Table 3). Prasad et al. reported the sensitivity of SSTR PET to be $87 \%$ in 13 patients (33). However, preliminary data from a prospective head-to-head comparison in 29 patients (NCT03189953) indicate that the sensitivity of GLP$1 \mathrm{R} \mathrm{PET/CT} \mathrm{is} 85 \%$ compared with $55 \%$ for SSTR PET/CT (32). This is in concordance with in vitro autoradiography results of Reubi et al. who found that only $69 \%$ of benign insulinoma tissue samples expressed the SSTR2 (15).
SSTR SPECT/CT shows an insufficient sensitivity in the localization of benign insulinomas. It ranges between $20 \%$ and $29 \%$, most probably due to the lower spatial resolution of this imaging modality $(24,27)$.

${ }^{18} \mathrm{~F}$-DOPA PET/CT can also be performed for localizing insulinoma, but data are scarce, retrospective, and controversial. Nakuz et al. detected the insulinoma in 5 of 10 patients $(50 \%)$ with ${ }^{18} \mathrm{~F}$ DOPA PET, whereas Imperiale et al. showed in 11 patients that detection rate of insulinomas with ${ }^{18} \mathrm{~F}$-DOPA PET can be improved (73\%) through serial scans (early plus late scan) and carbidopa pretreatment known to reduce physiologic uptake in the pancreas $(34,35)$. A prospective direct comparison of GLP-1R PET/CT and ${ }^{18} \mathrm{~F}$-DOPA PET/CT has not yet been performed.

\section{Other Applications of GLP-1R Imaging}

Another application for GLP-1R imaging is the detection of nesidioblastosis (hypertrophy/hyperplasia of pancreatic islets). This entity was first described in children and neonates and is a differential diagnosis of EHH. However, nesidioblastosis can also occur in adults (36). Clinically, the differential diagnosis between insulinoma and adult nesidioblastosis remains difficult, and the distinction between benign insulinoma, focal, or diffuse pancreatic nesidioblastosis is critical to suggest a treatment strategy. Although for childhood-onset nesidioblastosis ${ }^{18} \mathrm{~F}$-DOPA PET/CT appears to be a valid tool (37), preliminary data in adult nesidioblastosis indicate that GLP-1R imaging might be an alternative imaging procedure differentiating between insulinoma, focal, or diffuse nesidioblastosis (38).

Another cause of EHH is postprandial hypoglycemia, occurring several years after bariatric bypass surgery (20). In a small subset of individuals, this form of hypoglycemia is severe and unresponsive to nutritional and medical management, and partial pancreatectomy has to be performed for symptom control (39). There is an ongoing controversy whether this syndrome is associated with

\section{TABLE 3}

Performance of Different Imaging Modalities in the Localization of Insulinomas (Benign Insulinomas)

\begin{tabular}{|c|c|c|c|}
\hline Modality & Imaging modality & Sensitivity & Reference* \\
\hline \multirow{5}{*}{$\begin{array}{l}\text { Nuclear } \\
\text { medicine }\end{array}$} & GLP-1R PET/CT & $85 \%-98 \%$ & $(22,24,32)$ \\
\hline & GLP-1R SPECT/CT & $69 \%$ & (22) \\
\hline & SSTR PET/CT & $55 \%-87 \%$ & $(32,47)$ \\
\hline & SSTR SPECT/CT & $20 \%-29 \%$ & $(24,27)$ \\
\hline & ${ }^{18} \mathrm{~F}$-DOPA PET/CT & $50 \%-73 \%$ & $(34,35)$ \\
\hline \multirow[t]{2}{*}{ Radiology } & ceMRI & $56 \%-90 \%$ & $(22,23,24,25,26)$ \\
\hline & Multiphase ceCT & $47 \%-74 \%$ & $\begin{array}{c}(23,24,25,26, \\
27,35)\end{array}$ \\
\hline \multirow[t]{2}{*}{$\begin{array}{l}\text { Invasive } \\
\text { imaging }\end{array}$} & EUS & $70 \%-100 \%$ & $\begin{array}{r}(23,24,25,27, \\
35,48,49,50)\end{array}$ \\
\hline & ASVS & $65 \%-100 \%$ & $(27,48,49,51,52)$ \\
\hline
\end{tabular}

${ }^{\text {*} R e f e r e n c e s ~ i n c l u d e ~ a l l ~ E n g l i s h ~ w r i t t e n ~ l i t e r a t u r e ~ n o t ~ o l d e r ~ t h a n ~} 6$ y with more than 12 patients per study using the following keywords: localization of insulinoma or endogenous hyperinsulinemic hypoglycemia. Only exception are ${ }^{18} \mathrm{~F}$-DOPA PET/CT studies, as trials with more than 12 patients were not available.

EUS = endoscopic ultrasound; ASVS = selective intraarterial calcium stimulation and venous sampling. 


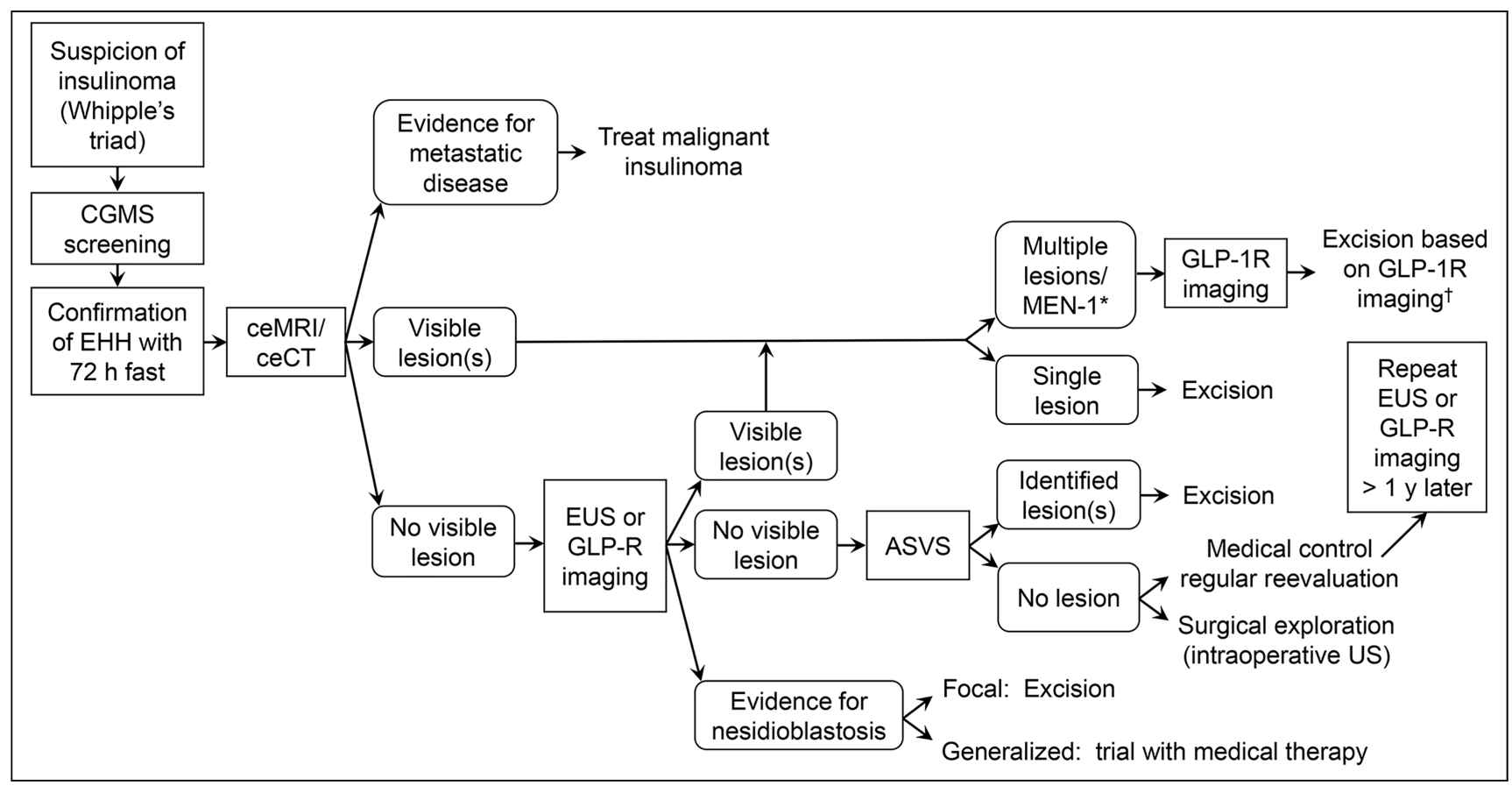

FIGURE 2. Proposed algorithm for evaluation of patients with suspected insulinoma. CGMS = continuous glucose monitoring system; EUS = endoscopic ultrasound; ASVS = selective intraarterial calcium stimulation and venous sampling; $y=$ year. *MEN-1 syndrome should be considered when multiple lesions are visualized. ${ }^{\dagger}$ GLP-1R PET/CT can differentiate between insulin-producing and nonfunctioning NET in patients with MEN-1 syndrome.

nesidioblastosis $(20,40)$. In vitro studies of surgical samples of patients with severe postbariatric hypoglycemia syndrome suggest that GLP-1R is not overexpressed in these islets compared with normal islets (Table 2).

$\beta$-cells represent only a tiny fraction of the volume of the pancreas $(1 \%-3 \%)$ and are scattered in the islets throughout the whole organ. Changes in pancreatic $\beta$-cell mass (BCM) contribute to the development of type 1 and type 2 diabetes mellitus, and the in vivo assessment of BCM is critical in patients with type 1 and type 2 diabetes, since drug development aims at preserving BCM and preventing BCM death (41). Although the efficacy of such new drug compounds is relatively easy to determine in mice and rats using postmortem histology, it is challenging to translate these results to humans (41). GLP-1R imaging could be a promising method for BCM quantification. However, recent GLP-1R imaging studies revealed marked differences only in patients with established type 1 diabetes (absence or presence of BCM) (42), indicating difficulties in the quantification of small signal changes in early onset type 1 diabetes or type 2 diabetes (41). Such limitations may prevent the detection of submaximal changes of $\mathrm{BCM}$ or their use in regenerative $\beta$-cell-targeted therapies.

Pancreatic islets transplantation is an established method for patients with brittle type 1 diabetes after kidney transplantation (43). However, the live span of graft survival is limited due to inflammatory processes, which cannot be easily detected by serum markers. To monitor the graft volume, a noninvasive method to visualize viable $\beta$-cells is critical. GLP-1R imaging has been shown to reliably quantify engrafted $\beta$-cells using an intramuscular islet transplantation model in mice and in humans $(44,45)$. This method has certainly potential, however, we need to keep in mind that skeletal muscle has no GLP-1R and, therefore, the BCM-to- background ratio is favorable. In contrast, background uptake of the liver, where the islets are usually engrafted, is somewhat higher (Fig. 1). Therefore, it remains to be demonstrated whether GLP-1R imaging in the context of transplanted islets holds its promise.

\section{Pitfalls, Adverse Effects, and Limitations of GLP-1R Imaging}

There are 2 groups of pitfalls/challenges that have to be considered while reading GLP-1R scans: peripancreatic uptake and missing focal uptake in the pancreas (46).

Peripancreatic uptake of radiolabeled exendin- 4 is often seen in Brunner's glands of the proximal duodenum. It is also the most common pitfall as Brunner's glands are always physiologically present. Uptake in Brunner's glands can be confused with an insulinoma or vice versa (46) (Fig. 1). Ectopic insulinomas, although extremely rare, can be another cause for peripancreatic uptake.

Biochemical evidence for an insulinoma but absence of focal radiolabeled exendin- 4 uptake in the pancreas might occur in the following situations: size of insulinoma below camera detection limit, insulinoma overlap with kidney uptake, no GLP-1R expression (malignant insulinoma), insulinoma is not localized in the pancreas (ectopic insulinoma), and other cause of EHH (e.g., nesidioblastosis) (46).

Injection of radiolabeled exendin- 4 can cause severe hypoglycemia in patients with EHH and nausea (30). Concomitant glucose infusion (e.g., 10\%, 1,000 mL for $5 \mathrm{~h}$ ) efficiently prevents hypoglycemia and is therefore recommended (22). Other adverse effects are nausea and sporadic vomiting. A low amount of radiolabeled exendin-4 (5-7 $\mu \mathrm{g})$ may prevent nausea and vomiting (32).

The main limitation of GLP-1R imaging is its limited availability as it is not yet authorized for routine clinical use. 


\section{CONCLUSION}

Prospective comparison studies indicate that GLP-1R PET/CT is not only more sensitive than GLP-1R SPECT/CT but also is the most sensitive noninvasive imaging modality to localize benign insulinomas and insulinomas in the context of MEN-1 (Table 3) $(19,22,24,32)$. Consequently, European Neuroendocrine Tumor Society guidelines recommend GLP-1R imaging or ASVS in patients with $\mathrm{EHH}$ with negative ceMRI/ceCT or negative EUS results (21). Furthermore, there is growing evidence that GLP-1R $\mathrm{PET} / \mathrm{CT}$ can visualize and localize adult nesidioblastosis. This is clinically relevant as the distinction between single and multiple insulinoma as well as focal and diffuse nesidioblastosis is critical to suggest a therapeutic strategy in these patients. Studies have proven the clinical relevance of GLP-1R imaging as it is often the only imaging modality (e.g., in 13/106 consecutive patients in the 3 largest prospective studies) able to localize the insulinoma or nesidioblastosis $(22,24,29)$. It is likely that this noninvasive imaging modality will replace the invasive localization of insulinomas with ASVS. We therefore propose a diagnostic algorithm that includes GLP-1R imaging for the evaluation of patients with EHH (Fig. 2).

Other more experimental indications for GLP-1R imaging include the diagnosis of an insulinoma/nesidioblastosis in patients with postprandial hypoglycemia after bariatric surgery and monitoring $\beta$-cells in patients with brittle type 1 diabetes after islet-cell transplantation.

\section{DISCLOSURE}

No potential conflict of interest relevant to this article was reported.

\section{ACKNOWLEDGMENTS}

The studies were supported by the Swiss National Science Foundation (grant number 320030-152938) and the Desirée and Niels Yde's Foundation (grant number 389-12), which had no role in study design, data collection, analysis, interpretation, or writing of the report.

\section{KEY POINTS}

QUESTION: Glucagon-like peptide-1 receptor as emerging target: will it make it to the clinic?

PERTINENT FINDINGS: Prospective comparison studies indicate that GLP-1R PET/CT is the most sensitive noninvasive imaging modality to localize benign insulinomas and insulinomas in the context of MEN-1. Furthermore, there is growing evidence that GLP-1R PET/CT can visualize and localize adult nesidoblastosis and probably focal nesidioblastosis in newborns, which is a form of congenital hyperinsulinism.

IMPLICATIONS FOR PATIENT CARE: GLP-1R PET/CT is likely to have an impact in the management of patients with endogenous hyperinsulinemic hypoglycemia as the localization and distinction of single and multiple insulinoma as well as focal and diffuse nesidioblastosis is critical to suggest a therapeutic strategy in these patients.

\section{REFERENCES}

1. Thorens B, Porret A, Buhler L, Deng SP, Morel P, Widmann C. Cloning and functional expression of the human islet GLP-1 receptor: demonstration that exendin-4 is an agonist and exendin-(9-39) an antagonist of the receptor. Diabetes. 1993;42:1678-1682.

2. Tornehave D, Kristensen P, Romer J, Knudsen LB, Heller RS. Expression of the GLP-1 receptor in mouse, rat, and human pancreas. $J$ Histochem Cytochem. 2008;56:841-851.

3. Nauck M. Incretin therapies: highlighting common features and differences in the modes of action of glucagon-like peptide-1 receptor agonists and dipeptidyl peptidase-4 inhibitors. Diabetes Obes Metab. 2016;18:203-216.

4. Gotthardt M, Fischer M, Naeher I, et al. Use of the incretin hormone glucagon-like peptide-1 (GLP-1) for the detection of insulinomas: initial experimental results. Eur J Nucl Med Mol Imaging. 2002;29:597-606.

5. Velikyan I, Eriksson O. Advances in GLP-1 receptor targeting radiolabeled agent development and prospective of theranostics. Theranostics. 2020;10:437-461.

6. Jansen TJP, van Lith SAM, Boss M, et al. Exendin-4 analogs in insulinoma theranostics. J Labelled Comp Radiopharm. 2019;62:656-672.

7. Wild D, Behe M, Wicki A, et al. [Lys40(Ahx-DTPA- ${ }^{111}$ In)NH2] exendin-4, a very promising ligand for glucagon-like peptide-1 (GLP-1) receptor targeting. $J$ Nucl Med. 2006;47:2025-2033.

8. Wild D, Wicki A, Mansi R, et al. Exendin-4-based radiopharmaceuticals for glucagon-like peptide-1 receptor PET/CT and SPECT/CT. $J$ Nucl Med. 2010;51:1059-1067.

9. Antwi K, Fani M, Nicolas G, et al. Localization of hidden insulinomas with ${ }^{68} \mathrm{Ga}$ DOTA-exendin-4 PET/CT: a pilot study. J Nucl Med. 2015;56:1075-1078.

10. Läppchen T, Tonnesmann R, Eersels J, Meyer PT, Maecke HR, Rylova SN. Radioiodinated exendin-4 is superior to the radiometal-labelled glucagon-like peptide-1 receptor probes overcomingtheir high kidney uptake. PLoS One. 2017; 12:e0170435.

11. Kiesewetter DO, Guo N, Guo J, et al. Evaluation of an $\left[{ }^{18} \mathrm{~F}\right] \mathrm{AlF}-\mathrm{NOTA}$ analog of exendin-4 for imaging of GLP-1 receptor in insulinoma. Theranostics. 2012;2:999-1009.

12. Selvaraju RK, Velikyan I, Johansson L, et al. In vivo imaging of the glucagon-like peptide 1 receptor in the pancreas with ${ }^{68}$ Ga-labeled DO3A-exendin-4. J Nucl Med. 2013;54:1458-1463.

13. Brom M, Joosten L, Oyen WJ, Gotthardt M, Boerman OC. Radiolabelled GLP-1 analogues for in vivo targeting of insulinomas. Contrast Media Mol Imaging. 2012;7:160-166.

14. Rylova SN, Waser B, Del Pozzo L, et al. Approaches to improve the pharmacokinetics of radiolabeled glucagon-likepeptide-1 receptor ligands using antagonistic tracers. J Nucl Med. 2016;57:1282-1288.

15. Reubi JC, Waser B. Concomitant expression of several peptide receptors in neuroendocrine tumours: molecular basis for in vivo multireceptor tumour targeting. Eur J Nucl Med Mol Imaging. 2003;30:781-793.

16. Körner M, Stockli M, Waser B, Reubi JC. GLP-1 receptor expression in human tumors and human normal tissues: potential for in vivo targeting. $\mathrm{J} \mathrm{Nucl} \mathrm{Med}$. 2007;48:736-743.

17. Reubi JC, Perren A, Rehmann R, et al. Glucagon-like peptide-1 (GLP-1) receptors are not overexpressed in pancreatic islets from patients with severe hyperinsulinaemic hypoglycaemia following gastric bypass. Diabetologia. 2010;53:2641-2645.

18. Wild D, Christ E, Caplin ME, et al. Glucagon-like peptide-1 versus somatostatin receptor targeting reveals 2 distinct forms of malignant insulinomas. $\mathrm{J} \mathrm{Nucl} \mathrm{Med}$. 2011;52:1073-1078.

19. Antwi K, Nicolas G, Fani M, et al. ${ }^{68} \mathrm{Ga}$-exendin-4 PET/CT detects insulinomas in patients with endogenous hyperinsulinemic hypoglycemia in MEN-1. J Clin Endocrinol Metab. 2019;104:5843-5852.

20. Service GJ, Thompson GB, Service FJ, Andrews JC, Collazo-Clavell ML, Lloyd RV. Hyperinsulinemic hypoglycemia with nesidioblastosis after gastric-bypass surgery. N Engl J Med. 2005;353:249-254.

21. Falconi M, Eriksson B, Kaltsas G, et al. ENETS consensus guidelines update for the management of patients with functional pancreatic neuroendocrine tumors and non-functional pancreatic neuroendocrine tumors. Neuroendocrinology. 2016;103:153-171.

22. Antwi K, Fani M, Heye T, et al. Comparison of glucagon-like peptide-1 receptor (GLP-1R) PET/CT, SPECT/CT and 3T MRI for the localisation of occult insulinomas: evaluation of diagnostic accuracy in a prospective crossover imaging study. Eur J Nucl Med Mol Imaging. 2018;45:2318-2327.

23. Fu J, Liu F, Yuan K, et al. The value of hybrid angio-CT in preoperative detection and localization of insulinomas: a single-center retrospective study. Cardiovasc Intervent Radiol. 2018;41:633-638.

24. Luo Y, Pan Q, Yao S, et al. Glucagon-like peptide-1 receptor PET/CT with ${ }^{68} \mathrm{Ga}-$ NOTA-Exendin-4 for detecting localized insulinoma: a prospective cohort study. $J$ Nucl Med. 2016;57:715-720.

25. Wei J, Liu X, Wu J, et al. Diagnosis and surgical management of insulinomas in 33 consecutive patients at a single institution. Langenbecks Arch Surg. 2016;401:1019-1025 
26. Zhu L, Xue H, Sun Z, et al. Prospective comparison of biphasic contrast-enhanced $\mathrm{CT}$, volume perfusion $\mathrm{CT}$, and 3 Tesla MRI with diffusion-weighted imaging for insulinoma detection. J Magn Reson Imaging. 2017;46:1648-1655.

27. Andreassen M, Ilett E, Wiese D, et al. Surgical management, preoperative tumor localization, and histopathology of 80 patients operated on for insulinoma. J Clin Endocrinol Metab. 2019;104:6129-6138.

28. Wild D, Macke H, Christ E, Gloor B, Reubi JC. Glucagon-like peptide 1-receptor scans to localize occult insulinomas. $N$ Engl J Med. 2008;359:766-768.

29. Christ E, Wild D, Ederer S, et al. Glucagon-like peptide-1 receptor imaging for the localisation of insulinomas: a prospective multicentre imaging study. Lancet Diabetes Endocrinol. 2013;1:115-122.

30. Christ E, Wild D, Forrer F, et al. Glucagon-like peptide-1 receptor imaging for localization of insulinomas. J Clin Endocrinol Metab. 2009;94:4398-4405.

31. Sowa-Staszczak A, Pach D, Mikolajczak R, et al. Glucagon-like peptide-1 receptor imaging with [Lys40(Ahx-HYNIC- ${ }^{99 m}$ Tc/EDDA)NH2]-exendin-4 for the detection of insulinoma. Eur J Nucl Med Mol Imaging. 2013;40:524-531.

32. Boss M, Mikkola K, Buitinga M, et al. ${ }^{68}$ Ga-NODAGA-exendin-4 PET/CT for the localization of insulinomas. Nuklearmedizin. 2019;58:124.

33. van Schaik E, van Vliet EI, Feelders RA, et al. Improved control of severe hypoglycemia in patients with malignant insulinomas by peptide receptor radionuclide therapy. J Clin Endocrinol Metab. 2011;96:3381-3389.

34. Imperiale A, Sebag F, Vix M, et al. ${ }^{18}$ F-FDOPA PET/CT imaging of insulinoma revisited. Eur J Nucl Med Mol Imaging. 2015;42:409-418.

35. Nakuz TS, Berger E, El-Rabadi K, et al. Clinical value of ${ }^{18}$ F-FDOPA PET/CT with contrast enhancement and without carbidopa premedication in patients with insulinoma. Anticancer Res. 2018;38:353-358.

36. Shah P, Rahman SA, Demirbilek H, Guemes M, Hussain K. Hyperinsulinaemic hypoglycaemia in children and adults. Lancet Diabetes Endocrinol. 2017;5:729-742.

37. Otonkoski T, Nanto-Salonen K, Seppanen M, et al. Noninvasive diagnosis of focal hyperinsulinism of infancy with $\left[{ }^{18} \mathrm{~F}\right]$-DOPA positron emission tomography. Diabetes. 2006;55:13-18.

38. Christ E, Wild D, Antwi K, et al. Preoperative localization of adult nesidioblastosis using ${ }^{68}$ Ga-DOTA-exendin-4-PET/CT. Endocrine. 2015;50:821-823.

39. Patti ME, McMahon G, Mun EC, et al. Severe hypoglycaemia post-gastric bypass requiring partial pancreatectomy: evidence for inappropriate insulin secretion and pancreatic islet hyperplasia. Diabetologia. 2005;48:2236-2240.
40. Meier JJ, Butler AE, Galasso R, Butler PC. Hyperinsulinemic hypoglycemia after gastric bypass surgery is not accompanied by islet hyperplasia or increased betacell turnover. Diabetes Care. 2006;29:1554-1559.

41. Laurent D, Vinet L, Lamprianou S, et al. Pancreatic beta-cell imaging in humans: fiction or option? Diabetes Obes Metab. 2016;18:6-15.

42. Brom M, Woliner-van der Weg W, Joosten L, et al. Non-invasive quantification of the beta cell mass by SPECT with ${ }^{111}$ In-labelled exendin. Diabetologia. 2014;57:950-959

43. Shapiro AM, Lakey JR, Ryan EA, et al. Islet transplantation in seven patients with type 1 diabetes mellitus using a glucocorticoid-free immunosuppressive regimen. N Engl J Med. 2000;343:230-238.

44. Eter WA, Van der Kroon I, Andralojc K, et al. Non-invasive in vivo determination of viable islet graft volume by ${ }^{111}$ In-exendin-3. Sci Rep. 2017;7:7232.

45. Pattou F, Kerr-Conte J, Wild D. GLP-1-receptor scanning for imaging of human beta cells transplanted in muscle. N Engl J Med. 2010;363:1289-1290.

46. Antwi K, Hepprich M, Muller N, et al. Pitfalls in the detection of insulinomas with GLP-1R imaging. Clin Nucl Med. 2020;45:e386-e392.

47. Prasad V, Sainz-Esteban A, Arsenic R, et al. Role of ${ }^{68} \mathrm{Ga}$ somatostatin receptor $\mathrm{PET} / \mathrm{CT}$ in the detection of endogenous hyperinsulinaemic focus: an explorative study. Eur J Nucl Med Mol Imaging. 2016;43:1593-1600.

48. Morera J, Guillaume A, Courtheoux P, et al. Preoperative localization of an insulinoma: selective arterial calcium stimulation test performance. J Endocrinol Invest. 2016;39:455-463.

49. Tavcar I, Kikovic S, Bezmarevic M, et al. A 60-year experience in the treatment of pancreatic insulinoma in the Military Medical Academy, Belgrade, Serbia. Vojnosanit Pregl. 2014;71:293-297.

50. Téllez-Ávila FI, Acosta-Villavicencio GY, Chan C, et al. Diagnostic yield of endoscopic ultrasound in patients with hypoglicemia and insulinoma suspected. Endosc Ultrasound. 2015;4:52-55.

51. Graf A, Sarlos S, Farrell SG, MacIsaac RJ, Inder WJ, Sachithanandan N. Selective intra-arterial calcium stimulation test for the localization of insulinomas: an Australian hospital experience. ANZ J Surg. 2020;90:E172-E176.

52. Moreno-Moreno P, Alhambra-Exposito MR, Herrera-Martinez AD, et al. Arterial calcium stimulation with hepatic xenous sampling in the localization diagnosis of endogenous hyperinsulinism. Int J Endocrinol. 2016;2016:4581094. 